\title{
Recent Advances on Renewable Energies and Carbon Capture
}

\author{
Kaize Zhang1, Juqin Shen ${ }^{1 *}$, Jinglai Zhang ${ }^{2 *}$, Han Han ${ }^{1}$ \\ ${ }^{1}$ School of Business, Hohai University, Nanjing, China \\ ${ }^{2}$ Department of Chemistry, College of Chemistry and Chemical Engineering, Henan University, Kaifeng, China
}

Received: 14 June 2018

Accepted: 23 July 2018

\begin{abstract}
In recent years, environmental pollution caused by excessive exploitation and utilization of the Earth's fossil fuels, extreme exploitation of land resources, and excessive emissions of carbon dioxide $\left(\mathrm{CO}_{2}\right)$ has caused people to think about how to reduce $\mathrm{CO}_{2}$ emissions and capture the existing $\mathrm{CO}_{2}$ in the atmosphere. The reduction of $\mathrm{CO}_{2}$ emissions can be summarized into two aspects. Firstly, people could use renewable energy to provide energy support for economic and social development. These renewable energies mainly include solar energy; wind energy, hydro, and marine energies; geothermal energy; and biomass energy. The second aspect is the sequestration and conversion of $\mathrm{CO}_{2} \cdot \mathrm{CO}_{2}$ is also a form of carbon resource that can be a favorable alternative to traditional carbon resources. The utilization of $\mathrm{CO}_{2}$ can solve both environmental pollution and depletion of traditional carbon resources at the same time. In this paper, the development of five renewable energy sources and their applications in China were discussed, and the methods of effective sequestration and conversion of $\mathrm{CO}_{2}$ were presented. Energy and environment are closely related to the development of modern society. The problems caused by excessive $\mathrm{CO}_{2}$ emissions cannot be ignored and the sequestration of the greenhouse effect requires joint efforts of mankind.
\end{abstract}

Keywords: carbon dioxide emissions; renewable energy sources; sequestration of carbon dioxide; status of development

\section{Introduction}

It is well-known that energy plays an essential role in industrialization and the progress of human society. In other words, energy resources are the foundation of the prosperity of society. With the increase of population, the requirement of energy resources is rapidly increased. However, traditional fossil fuel-based energies (coal,

*e-mail: jqshen@hhe.edu.cn, zhangjinglai@henu.edu.cn oil, and gas) are still dominant in energy supply, which account for $86 \%$ of total world energy generation [1].

In general, there are two major problems in the utilization of fuel-based energy in past decades. On the one hand, fossil fuel-based energy is nonrenewable. It has been reported that coal, oil, and gas would be exhausted in 52.9, 55.7, and 109 years, respectively, from previously recognized sources [2]. On the other hand, excessive reliance on fossil fuels has caused great environmental damage. The emission of carbon dioxide $\left(\mathrm{CO}_{2}\right)$, sulfur dioxide $\left(\mathrm{SO}_{2}\right)$, and other pollutants in the process of utilizing fossil fuel-based energy has led to 
serious environmental issues. The greenhouse effect aroused by $\mathrm{CO}_{2}$ is almost equivalent to the contribution of all other greenhouse gases. Therefore, $\mathrm{CO}_{2}$ is considered the synonym of greenhouse gas [3]. The emission of a great amount of carbon dioxide will raise global temperature and the sea level. In the long run, it would even change the global climate and cause immeasurable impact on mankind. Before industrialization (1750 A. D.), the average concentration of carbon dioxide in the global atmosphere was $278 \mathrm{ppm}$ [4]. It had increased to $390 \mathrm{ppm}$ in 2010, and had exceeded $403 \mathrm{ppm}$ in the end of 2016, and it is still growing. It has been confirmed that the utilization of fossil fuels is mainly responsible for the majority of global $\mathrm{CO}_{2}$ emissions. According to the data released by the World Meteorological Organization and the governments, the global average temperature in 2017 was higher by 1.1 degrees Celsius than that of the era before the industrial in about 1850 , which makes it the world's warmest year on record [5]. Data from the China Meteorological Administration also showed that the national average temperature in 2017 was 0.84 degrees Celsius higher than before, which is the third highest since 1951 [6]. In 2017, northern China, especially Inner Mongolia, suffered from one of the worst droughts in recorded history, resulting in crop losses, difficulties in drinking water for people and livestock, and desertification in the grasslands. The Intergovernmental Panel on Climate Change (IPCC) predicts that rising temperatures and declining rainfalls in the next 20 to 80 years will lead to a $20 \%$ to $36 \%$ reduction in major crops such as rice and wheat [7]. The shortage of food supplies will have a huge impact on developing countries with rapidly growing populations. If the issue was not properly solved, it could even lead to social instability and political crisis. Global warming also affects human health, living conditions, and sustainable development of society.

Reducing greenhouse gas emissions, developing a low-carbon economy, and improving the environment have become the consensus of all mankind [8]. Scientists all over the world need to provide more new technologies in the field of the capture and storage of carbon dioxide, the utilization of coal, and coal gasification.

China is one of the fastest-growing countries in renewable energy. According to a report in the BP Statistical Review of World Energy June 2017 [9], wind farms in the world grew at a rate of 15.6 a year in 2016, generating 959.5 TWhs, with the largest generating capacity being China, which overtook the United States in 2016. China's annual growth rate is $39.4 \%$, generating 241.0 TWhs of electricity, which accounts for $25.1 \%$ of the world's total electricity output. In 2016, photovoltaic power generation accounted for only $1.5 \%$ of the world's total electrical output. In addition, the global photovoltaic power generation volume is 333.1 TWhs, an annual increase of $29.6 \%$, with China accounting for $19.9 \%$ of the global total, and the United States taking second place at 17.1. Biomass can produce transport fuels such as ethanol fuel. In 2016, the largest producer of biofuels in the world was the United States, accounting for $48 \%$ of the global total. By contrast, China was lagging behind, accounting for only $2.6 \%$. Geothermal power generation in the world was most common in the United States, accounting for $26.8 \%$ of the world's total in 2016, followed by the Philippines, Indonesia, New Zealand, etc. China's share is weak and negligible.

There are two major pathways to reduce $\mathrm{CO}_{2}$ emissions. One is to replace fossil fuels with renewable energies, which would completely eradicate $\mathrm{CO}_{2}$ emissions. In 2012, 22\% of total world energy generation was supplied by renewable energy sources, which would have been unimaginable a decade ago [10]. It is reasonable to believe that renewable energy sources will play a more important role in the future. The other aspect is to capture the $\mathrm{CO}_{2}$ that has already released into the atmosphere to alleviate its bad effects. Moreover, it is on the basis of the premise that there is no more $\mathrm{CO}_{2}$ emission, which is impossible in the foreseeable future. It would take even longer for the concentration of carbon dioxide to recover to a reasonable level. MacDowell proposed that only $0.5 \%$ to $5 \%$ of carbon emissions can be used based on current and future $\mathrm{CO}_{2}$ utilization, so carbon storage technology is an inevitable demand. Therefore, capture and use are not effective methods to reduce carbon dioxide in the atmosphere without storage [11]. $\mathrm{CO}_{2}$ capture, utilization, and storage are effective way to reduce the amount of carbon dioxide in the atmosphere as soon as possible.

It is good news that the two aspects have been greatly developed in the past two decades. In this paper, we review some progresses of those two aspects in recent years, summarize some problems that affect their large-scale applications, and provide some suggestions on the solutions. It is expected that this article would provide a new understanding of various renewable energy sources, and the proposed solution could be verified in future research.

\section{Renewable Energy Sources}

\section{Solar Energy}

Solar energy is one of the most ideal renewable energy sources, which is clean, inexhaustible, and free from regional restriction. The sun emits energy at a rate of $3.8 \times 10^{23} \mathrm{~kW}$ per second, and in one year the Earth's surface would accept solar radiation of 3,400,000 EJ, which is 7,500 times larger than the world's total annual primary energy consumption [12]. In other words, the solar energy absorbed by the Earth's surface every minute can meet the energy need of our planet for a year. According to the Renewables 2017 Global Status Report, global renewable energy has a $23.7 \%$ share of the electricity supply in 2015 and it is estimated to increase to $24.5 \%$ in 2016 [13]. In the future, the proportion of solar energy in total energies will increase year by year. 


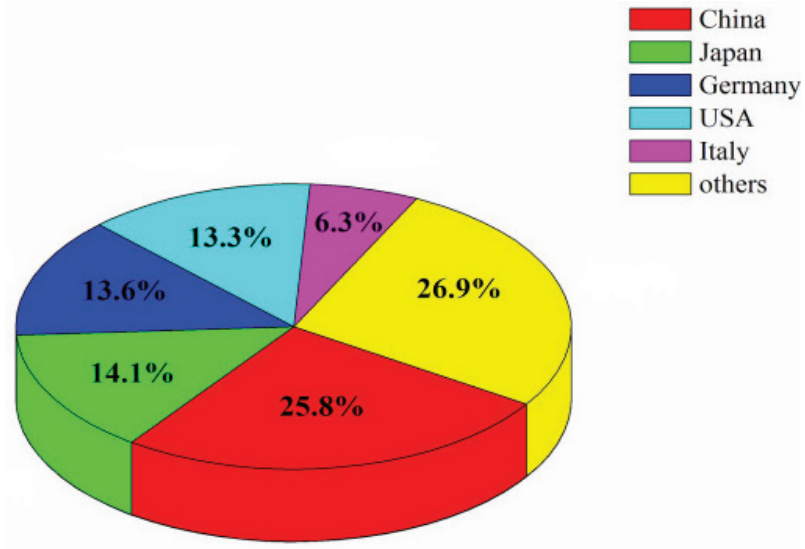

Fig. 1. Cumulative installed capacity percentages of various countries in 2016.

Photovoltaic power generation is one of the ways to effectively use solar energy, which has attracted widespread attention from all walks of life.

Since the 1980s, the solar power industry, which is one of the fastest growing high-tech industries, has risen sharply at an unbelievable rate. Before 2004, the cumulative installed capacity of global photovoltaic power was only 964.9 MW. By the end of 2016, the aggregated installed capacity of global photovoltaic power had reached $303 \mathrm{GW}$ [13]. The United States is the first country in the world to develop plans for a photovoltaic power station. Japan has made a "new sunlight plan" and Germany has enacted a renewable energy law, vigorously promoting the development of the photovoltaic power industry. After that, Italy, Switzerland, and France also made photovoltaic plans. By the end of 2016, the top five countries of photovoltaic power are China, Japan, Germany, the United States, and Italy (Fig. 1).

Solar resource is abundant in China, equivalent to 1.7 trillion tons of coal per year. More than twothirds of the country's areas can receive radiation of more than $5000 \mathrm{MJ} / \mathrm{m}^{2}$, and more than 2200 hours per year of sunshine [14]. Therefore, it is reasonable to develop solar photovoltaic in China. The development of solar photovoltaic in China could be traced back to the 1970s.

In 1979, the first silicon-based solar cell was produced. Since then, the development of solar photovoltaic has been steady. In the 21th century, the construction of a photovoltaic power station developed rapidly. As shown in Fig. 2, China's cumulative installed capacity of photovoltaic power increased from $864 \mathrm{MW}$ in 2010 to $28.05 \mathrm{GW}$ in 2014. In 2015, newly installed capacity of photovoltaic power was about $15.13 \mathrm{GW}$ in China, which was equal to $28.3 \%$ in global new installed capacity. By the end of 2016, the cumulative installed capacity of photovoltaic amounted to $77.42 \mathrm{GW}$, which is the highest in the world [15]. China's photovoltaic power generation reaches 39.2 billion $\mathrm{kWh}$, which is equal to 15.68 million tons of standard coal, reducing

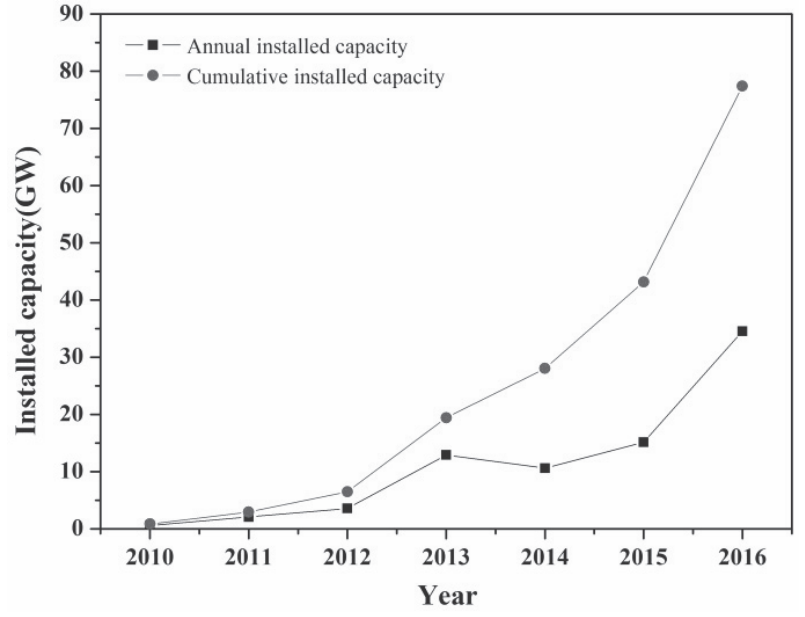

Fig. 2. Annual installed capacity and cumulative installed capacity of China from 2010 to 2016.

carbon dioxide emissions by 39 million tons [16]. It is expected that the generation of China's photovoltaic power reaches 200 billion $\mathrm{kWh}$ in 2020, which is equal to 80 million tons of standard coal and can reduce 199 million tons of carbon dioxide emissions. The construction of photovoltaic power stations has had an effective influence in curbing environmental pollution and reducing $\mathrm{CO}_{2}$ emissions.

Rapid declines in installation costs and increased capacity factors have improved the economic competitiveness of solar photovoltaic around the world. The global weighted average leveled cost of electricity of utility-scale photovoltaic plants is estimated to have fallen by $73 \%$ between 2010 and 2017, from around USD 0.36 to USD $0.10 / \mathrm{kWh}$. Performance guarantees of photovoltaic modules usually last over a period of 25 years. Taking as an assumption a lifetime of 25 years and an energy yield of $1000 \mathrm{kWh} / \mathrm{y} / \mathrm{kWp}$, photovoltaic production can produce $25000 \mathrm{kWh} / \mathrm{kWp}$ during its period [17].

On the basis of the status of solar energy utilized around the world, the percentage of solar energy accounts for a small proportion of total energy utilization. The existing problems include difficulty of energy storage, low efficiency, and high cost for the devices. But in the long run, using solar energy will help change traditional energy structures, overcome the energy crisis, curb global warming, and improve the ecological environment. The government has raised investment in solar energy. In general, solar power will play an increasingly important role in human life and economic development.

\section{Wind Energy}

Wind is one of the most familiar natural phenomena, which is caused by the differential heating of the Earth's surface by the sun. Therefore, wind is an indirect form of solar energy and is also a form of 
solar energy conversion [18]. In comparison to other energy resources, wind energy is abundant, renewable, very rich in most areas, and environmentally friendly. Wind energy transfers the kinetic energy caused by atmospheric motion into other forms of energy, which is applied in various regions. Among them, wind electricity is the most mature means of utilization with best prospects for commercial development and largescale applications. It is estimated that wind energy sources in the world are as high as 53 trillion $\mathrm{kWh}$, which is twice larger than the world's electricity demand in 2020. Wind power could reduce consumption of 0.31-0.34 kg standard coal per $\mathrm{kWh}$. Correspondingly, $\mathrm{CO}_{2}$ emissions would be decreased by $0.853-0.935 \mathrm{~kg}$ along with $\mathrm{SO}_{2}$ and other pollutants [19].

In 1891, Denmark built the first wind-driven generator [20]. After that, the wind turbine has been widely utilized worldwide. Since the beginning of the 21st century, the development and utilization of wind power has achieved unprecedented and rapid development worldwide. According to a report by the International Energy Agency, electricity generated by wind power accounted for $0.5 \%$ of global electricity generation in 2004. The global installed wind energy capacity in 2008 was $121 \mathrm{GW}$, which produced $260 \mathrm{TWh}$ of electricity and saved 158 million tons of $\mathrm{CO}_{2}[21,22]$. More than $38 \mathrm{GW}$ of new wind power capacity was installed around the world in 2009, leading to a total installed capacity of up to $158.5 \mathrm{GW}$ [23]. Despite the decrease in annual installations, global installed wind power capacity increased by $24.1 \%$ during the year, and now stands at $197.0 \mathrm{GW}$ [24]. The new global total installed wind power capacity at the end of 2011 was $238 \mathrm{GW}$, representing cumulative market growth of more than $20 \%$ [25]. In 2012, the annual market grew by about $10 \%$ to just under $45 \mathrm{GW}$, and a cumulative installed capacity up to $282.5 \mathrm{GW}$ globally [26]. More than 80 countries have commercial wind power.

The new global total installed wind power capacity at the end of 2013 was $318.12 \mathrm{GW}$, representing cumulative market growth of more than $12.5 \%$ [27]. Global cumulative installed capacity reached $370 \mathrm{GW}$ at the end of 2014 and in Europe 130 GW. The installed capacity at the end of 2014 in the EU produces 265 TWh of electricity every year on average [28]. Total cumulative installations stood at $433 \mathrm{GW}$ at the end of 2015 , representing cumulative growth of $17 \%$. This record was led by China's annual capacity addition, which alone accounted for $48 \%$ of the annual market [29]. On 5 May 2017, the annual global wind report was released by the Global Wind Energy Council (GWEC). The industry chalked up $12.6 \%$ growth in cumulative capacity with a $54.6 \mathrm{GW}$ market, leading to a total cumulative capacity of $486.8 \mathrm{GW}$ at the end of 2016. China, the USA, and Germany are still the top three countries in total cumulative installations. France, Turkey, and the Netherlands have excellent performance in 2016 [30]. Global wind installed capacity increases at

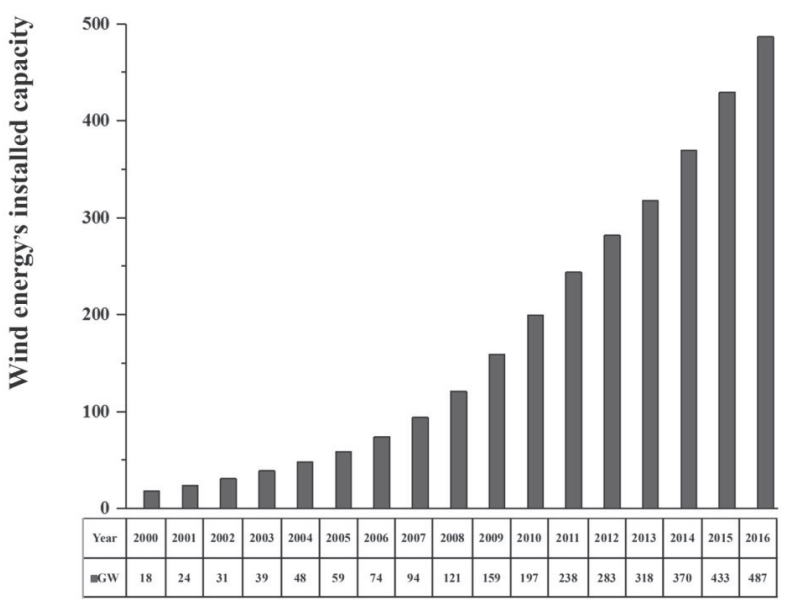

Fig. 3. Global annual installed wind capacity GW, 1994-2016 [20-30].

a sharp rate for decades. Global annual installed wind capacity from 1994 to 2016 is shown in Fig. 3.

Wind power has distinct advantages and competitiveness with comparison to other energy sources, which mainly include the following items: (i) it is cheap to build a wind power plant, which is much cheaper than the cost of building a hydropower station, thermal power plants, and nuclear power station [31]; (ii) electricity could be generated without the requirement for coal, oil, and other fuels or nuclear materials; (iii) wind energy is clean, no pollution and it develops rapidly [28]. The most important component in the wind power industry's power generation system is wind turbines. Among them, rare elements are essential in wind turbine permanent magnets. The environmental impact associated with mining of rare elements can also be considered; (iv) the time for construction of a wind power plant is short; (v) wind power is easy to operate without guards; (vi) it can be built on hills, the sea, embankments, and the desert; (vii) wind power generation could be operated independently and/or in network, which is possible to solve the problem of power to remote areas without electricity.

\section{Hydro and Marine Energies}

The special function and superiority of hydro energy have been recognized by various countries $[32,33]$. It is favorable for the economical and natural development to identify the water resources as a growth priority. Fossil fuels will be depleted in the future. However, hydro resources are renewable, which can be regenerated by rainfall. Therefore, water resources could be regarded as inexhaustible.

The sustainable utilization of water resources is a reasonable and effective way to maintain coordinated development and benign cycle of society and the economy [34]. It also shows great significance in meeting the requirement of energy. Generalized water resources 
include river hydropower and marine energy. River hydropower would be converted directly into electricity by use of the potential energy of water, including river flow. It is a completely physical and clean process without consumption, pollution, emission of waste gas, and other wastes. As long as the rivers do not dry up, hydropower is not exhaustible, which has been accepted by the international community and most energy experts [35]. Certainly, certain environmental pollution will also occur during the process of hydropower projects. For example, the Three Gorges Dam in China uses a lot of cement, and cement emissions can reach $5 \%$ of global carbon dioxide [36]. In 2002, the World Summit on Sustainable Development (WSSD) was held in South Africa. One of the main themes of the summit was "sustainable development," that is, how we can continue developing the world without pollution. It was confirmed in summit that the development of hydropower is one of the efficient pathways to reducing emissions of greenhouse gases and accomplishing sustainable development.

At the end of the $19^{\text {th }}$ century, electricity could be generated by hydropower. Cragside was the first hydro-powered house in 1878. The first commercial hydropower station was built at Niagara Falls in 1879. Two years later, lamps in the city of Niagara Falls were powered by hydroelectricity. Hydropower is currently in use in about 150 countries. According to the global status report published by the renewable energy policy network for the 21th century, the total installed capacity was increased year after year from 2008 to 2016 [12]. As shown in Fig. 4, global electricity generation from hydropower reached $885 \mathrm{GW}$ in 2008, which was increased to $1096 \mathrm{GW}$ by the end of 2016 . The growth of hydropower in 2013 was the highest, with new capacity of $37 \mathrm{GW}$, leading to a total capacity reaching an estimated 1,055 GW. China, Brazil, Canada, India, and Russia are the top five countries for hydro capacity.

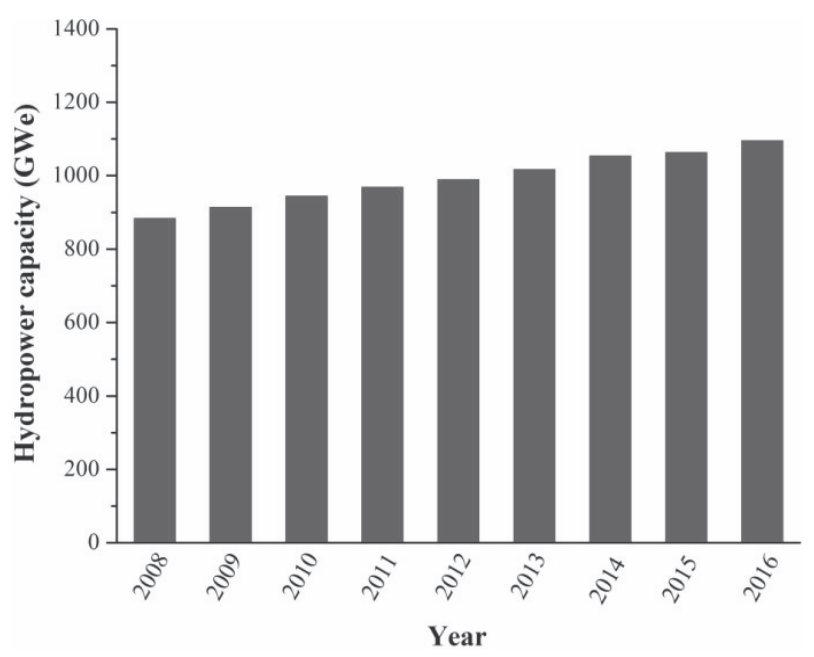

In China, the installed hydro capacity reached $100 \mathrm{GW}$, which would be increased to $250 \mathrm{GW}$ in 2020. One trillion kilowatt hours of electricity would be contributed by hydraulic power capacity if it utilized 4000 hours per year, which is equal to the electricity generated by $5 \times 10^{8} \mathrm{t}$ coal. Moreover, hydropower would save $9.26 \times 10^{8}$ tons of $\mathrm{CO}_{2}, 6.31 \times 10^{6}$ tons of $\mathrm{SO}_{2}, 2.52 \times 10^{6}$ tons of $\mathrm{NO}_{2}$, and $2.27 \times 10^{6}$ tons of smoke and dust in the air. Hydropower, as a clean energy resource with almost no emission of greenhouse gas, has received first-degree utilization and development across the world. The development and utilization of hydropower can meet the demands of energy, optimize energy structure, reduce greenhouse gas emissions, and promote sustainable development of society.

In addition to river hydropower energy, marine energy is also an important water energy resource. The ocean covers $70 \%$ of the earth, its available energy greatly exceeds the current total of global energy demand, and marine energy is a green and clean renewable energy source, so scientific development and utilization are important for alleviating energy crisis and environmental pollution issues. There are various types of marine energy, including wave energy, tidal energy, and temperature difference energy. Humans began studying the use of marine energy at the end of the 18th century, but did not implement it because of poor operating conditions. The development of modern science and technology, especially the development of materials, seals, and anti-corrosion technologies, has laid the foundation for the use of marine energy. In recent decades, marine energy power generation technology has achieved rapid development. Scientific and technological workers in various countries have developed various wave energy, tidal energy, and temperature difference power generation systems. Some of them have already built pilot power stations and entered commercial operations. It can be predicted that in the near future, marine energy generation will become another mature renewable energy power generation system after wind power generation and photovoltaic power generation.

China has a long coastline, rich ocean energy resources, and economically developed eastern coastal areas of China, where the power load is intensive and the power grid is powerful, creating favorable conditions for the development and utilization of large-scale ocean energy. At the same time, China is implementing developmental strategies such as the development of marine resources and renewable energy. Marine energy, as an important marine resource and clean energy, is an inevitable requirement for the development strategy of the country. It can be seen that the development and utilization of ocean energy will inevitably become a hot topic of research. Ocean energy is an important part of China's future energy structure. Therefore, we should make full use of hydro and marine energies as soon as possible.

Fig. 4. Total installed capacity from 2008 to 2016. 


\section{Geothermal Energy}

Sustainable development has attracted extensive attention worldwide. Since the beginning of the 20th century, foreign energy companies have focused on geothermal exploitation and utilization by the support and encouragement from the government, which is regarded as a new economic growth point. Geothermal energy has been exploited for decades to generate electricity both in space heating and industrial processes. Geothermal electrical installed capacity in the world was 7974 MW in 2000, and the electrical energy generated was 49.3 billion $\mathrm{kWh} /$ year, representing $0.3 \%$ of the world's total electrical energy. In developing countries, geothermal energy can also play a vital role. In the Philippines, $21 \%$ of electricity comes from geothermal steam, $20 \%$ in El Salvador, $17 \%$ in Nicaragua, 10\% in Costa Rica and $8 \%$ in Kenya. Electricity is produced with an efficiency of $10-17 \%$ [37]. Technological developments like enhanced geothermal systems (EGS) are regarded as the key to accelerating geothermal development.

In the development of geothermal energy, there are three major problems: universal applicability, long-term performance, and economic viability of EGS systems. The increasing deployment of geothermal heat pump systems promotes the utilization of geothermal direct use development. In several countries such systems already exhibit exponential growth and it is expected that this trend can continue. The future prospects of geothermal energy in general, and of power generation in particular, will depend on the gear change in further growth. Geothermal energy would play a significant role in a future energy supply scheme only when exponential growth is achieved. The growth rates of installed capacity and annual energy used over the past 20 years are shown in Fig. 5 [38].

Geothermal resources are rich in China, which is close to $8 \%$ of the total around the world. However, the distribution of this kind of energy is uneven. The high

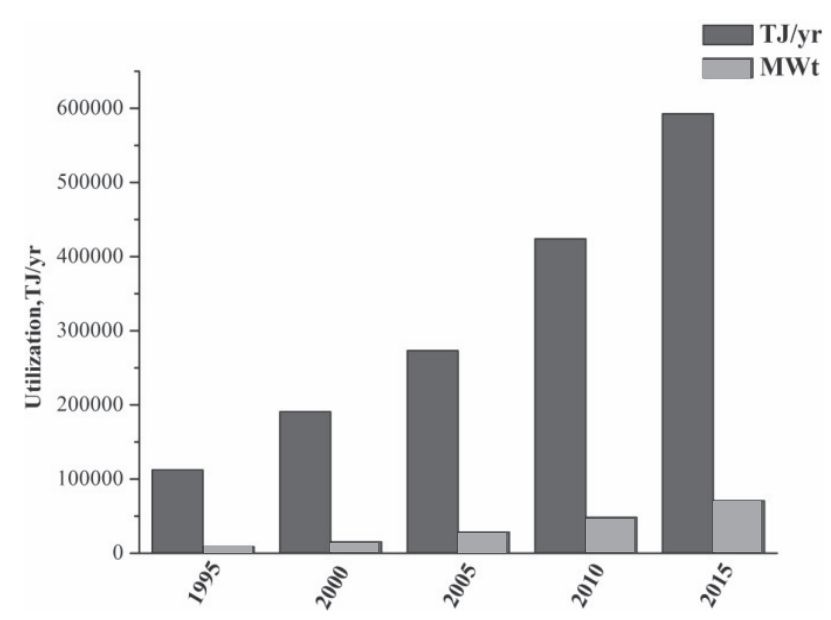

Fig. 5. Growth rates of installed capacity and annual energy used from 1995 to 2015. temperature geothermal resources are mainly distributed in Tibet, Yunnan, and Taiwan. While the low-medium temperature geothermal resources are almost distributed over all provinces [39].

According to official figures released by China's Ministry of Land and Resources (MLR) from 2009-2011 the shallow geothermal resources in China equalled 95 hundred million tons of standard coal. If they were fully utilized, it would save 2.5 hundred million tons of standard coal and reduce the emissions of $\mathrm{CO}_{2}$ by about 5 hundred million tons. The geothermal resources of sedimentary basin amount to 8530 hundred million tons of standard coal. The typical geothermal resources of sedimentary basin are about 6.4 hundred million tons of standard coal per year with the reduction of 13 hundred million tons $\mathrm{CO}_{2}$ emissions. The total hot dry rock (HDR) resources distributed at depths of $3-10 \mathrm{~km}$ are equivalent to 8600 thousand tons of standard coal, which is 26 thousand times the capacity of annual energy consumption in the mainland of China. In other words, they can be used for about 260 thousand years for national consumption [40].

In the late 1970s, several industrial geothermal power plants using high-temperature geothermal resources with total installed capacity of $28.18 \mathrm{MWe}$ were built in Yangbajain and Langjiu of Tibet. In 1977, a 1 MWe test unit was installed in Yangbajain and the other 8 units (3 MWe/unit) were installed from 1981 to 1991 progressively. From 1977 to the end of 2011, the cumulative electrical power of 26.79 hundred million $\mathrm{kWh}$ was generated by Yangbajain station. As a result, it saved 884 thousand tons of standard coal and reduced 3180 thousand tons of carbon dioxide emissions. Each year, about $40 \%$ of the electricity in Tibet is provided by Yangbajain in summer, and it is more than $60 \%$ in winter [41]. Geothermal power plants are of important strategic significance for Tibet's economic development and environmental protection.

In the direct utilization of low-temperature geothermal water in China, heating accounts for $18.0 \%$, medical treatment and recreation for $65.2 \%$, cultivation and cultivation for $9.1 \%$, and others $7.7 \%$. Geothermal heating is mainly concentrated in large and mediumsized cities like Beijing, Tianjin, Xi'an, and Zhengzhou, as well as towns in the northern oil mining areas, where geothermal water is used to heat buildings [42]. In 1990, only 1900 thousand $\mathrm{m}^{2}$ of buildings were heated by geothermal energy, while it was increased to 11000 thousand in 2000. It is estimated that the cost would be reduced by $30 \%$ by geothermal heating as compared to that used by coal.

Since 2006, the heating capacity of geothermal areas in China has increased by about $10 \%$ a year to $1291 \mathrm{MWt}$ and $14798.5 \mathrm{TJ} / \mathrm{year}$, and there has been a large increase in heat pump capacity from $383 \mathrm{MWt}$ (2004/5) to $5210 \mathrm{MWt}$ and $29035 \mathrm{TJ} / \mathrm{yr}$ in 2009. More than 1 million people use 26.4 million $\mathrm{m}^{3}$ geothermal water annually in Tianjin, which saves 1.17 million tons of standard coal and reduces $\mathrm{CO}_{2}$ emissions 


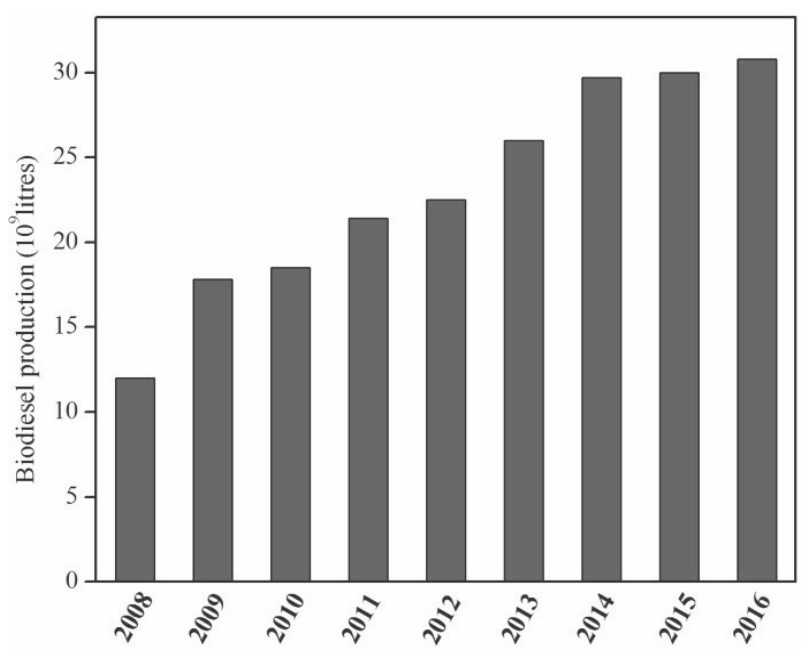

Fig. 6. Biodiesel production from 2008 to 2016.

by 2.78 million tons. The utilization of geothermal water includes $147 \mathrm{MWt}$ and $1687.9 \mathrm{TJ} / \mathrm{yr}$ for heating, $197 \mathrm{MWt}$ and $2170.8 \mathrm{TJ} / \mathrm{yr}$ for fish farming, $82 \mathrm{MWt}$ and $1037.5 \mathrm{TJ} / \mathrm{yr}$ for agricultural drying, $145 \mathrm{MWt}$ and $2732.6 \mathrm{TJ} / \mathrm{yr}$ for industrial process heating, and $1826 \mathrm{MWt}$ and 23,886.0 $\mathrm{TJ} / \mathrm{yr}$ for bathing and swimming. Geothermal water is mainly utilized for bathing, agriculture, and fish farming. The total is $8898 \mathrm{MWt}$ and 75,348.3 TJ/yr [43].

\section{Biomass Energy}

Biomass energy is a kind of energy that is directly or indirectly derived from the photosynthesis of plants, including animals, plants, and microbes. The carbon could be sequestrated by soil and wood through biomass. Then, fossil fuels would be replaced by wood energy to reduce $\mathrm{CO}_{2}$ emissions, which is beneficial for sustainable development [44].

Bioethanol is one of the most widely used biofuels in the world. The amount of $\mathrm{CO}_{2}$ to generate biomass is equivalent to that of $\mathrm{CO}_{2}$ released by combustion. Ver Heck argued that If these NEs were completely used for balancing fossil fuel emissions, primary

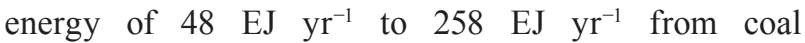
could be offset (based on an emission factor of $90 \mathrm{gCO}_{2}$-eq/MJth for coal20), depending on the

Table 1. Potential of food waste to electricity in some countries.

\begin{tabular}{|c|c|c|c|c|}
\hline Country & $\begin{array}{l}\text { National energy } \\
\text { consumption } \\
(\mathrm{TW} \mathrm{h})^{*}\end{array}$ & $\begin{array}{l}\text { Total potential } \\
\text { electricity-based } \\
\text { FW (TW h) }\end{array}$ & $\begin{array}{c}\text { Electricity potential from } \\
\text { FW conversion per capita } \\
\text { (kW h/capita) }\end{array}$ & $\begin{array}{c}\text { Sharing percentage in total } \\
\text { national electricity generation } \\
(\%)\end{array}$ \\
\hline Australia & 244.8 & 0.71 & 30.5 & 0.29 \\
\hline Brazil & 557 & 10.47 & 52.2 & 1.88 \\
\hline Canada & 627 & 8.44 & 240.0 & 1.35 \\
\hline China & 5362 & 60.94 & 44.9 & 1.14 \\
\hline Denmark & 35 & 0.25 & 44.0 & 0.71 \\
\hline Germany & 634 & 3.83 & 47.5 & 0.60 \\
\hline India & 1103 & 22.49 & 18.0 & 2.04 \\
\hline Ireland & 25 & 0.31 & 68.0 & 1.23 \\
\hline Japan & 1088 & 10.00 & 78.5 & 0.92 \\
\hline The Netherlands & 95 & 2.76 & 164.4 & 2.90 \\
\hline New Zealand & 43 & 0.08 & 18.1 & 0.19 \\
\hline Singapore & 48 & 0.25 & 46.1 & 0.52 \\
\hline South Africa & 256 & 2.83 & 47.4 & 1.10 \\
\hline South Korea & 535 & 1.95 & 38.8 & 0.36 \\
\hline Sweden & 160 & 0.60 & 62.4 & 0.37 \\
\hline Taiwan & 252 & 0.72 & 31.1 & 0.29 \\
\hline Thailand & 165 & 2.91 & 44.4 & 1.77 \\
\hline The United Kingdom & 357 & 4.69 & 73.1 & 1.31 \\
\hline The United States & 4260 & 19.02 & 60.2 & 0.45 \\
\hline Vietnam & 130 & 1.79 & 20.0 & 1.38 \\
\hline
\end{tabular}

"Note: Data were documented in the 63rd edition of the BP Statistical Review of World Energy (Bob, 2014) [48] 
Table 2. Biomass-based electricity production potential in 2030.

\begin{tabular}{|c|c|c|c|}
\hline Biomass source & Quantity & $\left(\mathrm{E}_{\mathrm{HHV}}\right) \mathrm{TWh} *$ & $\left(\mathrm{E}_{\text {output }}\right) \mathrm{TWh}$ \\
\hline \multicolumn{4}{|c|}{ Forest } \\
\hline Round wood for energy (MBDt) & 2.82 & 15.43 & 5.09 \\
\hline Mill residues (MBDt) & 2.41 & 14.13 & 4.66 \\
\hline Forest and roadside residue (MBDt) & 0.24 & 1.41 & 0.46 \\
\hline Mountain Pine Beetle wood n(MBDt) & 2.72 & 14.88 & 4.91 \\
\hline \multicolumn{4}{|c|}{ Agricultural biomass } \\
\hline Lignocellulosic feedstocks (MBDt) & 7.45 & 39.09 & 12.90 \\
\hline \multicolumn{4}{|c|}{ Municipal solid waste } \\
\hline Biomass-based fraction (MBDt) & 2.70 & 14.90 & 4.92 \\
\hline Total biomass energy content & & 99.84 & 32.95 \\
\hline
\end{tabular}

*Note: TWh is an energy unit equivalent to $3.6 \mathrm{PJ}$

biomass conversion pathway and socioeconomic landuse scenario [45]. So biomass could be regarded as no $\mathrm{CO}_{2}$ emission in the combustion. A sugarcanebioethanol system has higher yields of net energy and net potential of reducing GHG emissions than gasoline, as no energy is required to depolymerize carbohydrate into fermentable sugars [46]. Globally, bioethanol production grew from 17,000 to 65,614 million litres from 2006 to 2008 , respectively. In 2015, global bioethanol production reached up to 25576 million gallons (Fig. 6) with a maximum share of $57 \%$ from the USA. Moreover, it is estimated that bioethanol will provide $7 \%$ of total global energy as a transportation fuel by 2030 [47].

Food waste (FW) could be converted to electricity and heat energy and it can be used as a source of bioenergy. The five top countries that attained the highest heating values from annual FW were Canada (4915 MJ/capita), the Netherlands (3367 MJ/capita), the United Kingdom (1497 MJ/capita), Japan (1608 MJ/capita), and Sweden (1278 MJ/capita). Some countries could derive electricity from annual FW production and contribute a high percentage of total national electricity generation, such as The Netherlands e 2.9\% (164.4 kW h/capita), Canada e $1.35 \%$ (240 kW h/capita), Japan e $0.92 \%(78.5 \mathrm{~kW} \mathrm{~h} /$ capita), the United Kingdom 1.31\% (73.1 kW h/capita), and Ireland $1.23 \%$ (68 $\mathrm{kW} \mathrm{h/capita).} \mathrm{The} \mathrm{corresponding}$ data are listed in Table 1.

Although the global production of biofuels is still relatively low currently, they are continuously increasing [49]. Annual biodiesel consumption in the United States was 15 billion litres in 2006. It had been growing at a rate of $30-50 \%$ per year to achieve an annual target of 30 billion litres at the end of 2012 [50]. Some works have analyzed the potential of biomassbased energy from both energy and greenhouse gas reduction [51]. As shown in Table 2, Biomass energy from agriculture and forestry had the potential to save
$11 \%$ and $15 \%$ of total GHG emissions from energy production and address approximately $14 \%$ and $17 \%$ of the energy use final demand in 2030 for Alberta. In other words, biomass-based electricity production had the potential to substitute $29 \%$ of the total electricity consumption of Alberta. On the other hand, $33 \mathrm{TWh}$ of bioenergy electricity corresponded to nearly $9 \%$ of global electricity generation (IEA, 2013).

As a large agricultural country, China is rich in biomass resources. The annual available amount of agricultural residues throughout the country equals 440 million tce. The annual available amount of forest residues accounts for 350 million tce, and the annual available amount of manure all over the country equals 28 million tce. The annual available amount of municipal solid waste in China is equivalent to 12 million tce. Based on abundant biomass resources, China's biomass power generation industry has developed rapidly. In the future, biomass energy would play a more and more important role in China. It is estimated that China's total exploitable biomass energy in 2020 is around 0.7 billion tce, and exploitable biomass energy that could be used as energy would reach 0.45 billion tce.

\section{Capture and Conversion of $\mathrm{CO}_{2}$}

The proportion of greenhouse gases in global warming is $60 \%$ for $\mathrm{CO}_{2}, 20 \%$ for $\mathrm{CH}_{4}, 6 \%$ for $\mathrm{N}_{2} \mathrm{O}, 14 \%$ for $\mathrm{CF}_{11}$ and $\mathrm{CFC}_{12}$, etc. As the most famous greenhouse gas, carbon dioxide is regarded as a synonym for greenhouse gas. Various renewable energies have been developed to reduce $\mathrm{CO}_{2}$ emissions. Carbon dioxide is also an abundant and cheap carbon resource, which is the potential alternative for traditional carbon resources. If the emitted $\mathrm{CO}_{2}$ could be fully utilized, issues of both the pollution and depletion of traditional fossil fuels could be resolved.

Two major methods have been employed to utilize $\mathrm{CO}_{2}$. One method is to use $\mathrm{CO}_{2}$ to synthesize various 
substances, which could be intermediates in the production of pharmaceuticals and fine chemicals. For example, $\mathrm{CO}_{2}$ could react with $\mathrm{PO}$ to produce the five-membered cyclic carbonates, which has wide applications as electrolytic elements in lithium batteries, precursors of polycarbonates and other polymers [52, 53]. More than 25 pathways have been available for the chemical fixation of $\mathrm{CO}_{2}$ to produce methanol, formaldehyde, formic acid, and benzoic acid [54]. One of the most important raw materials to synthesize them is fossil fuels. If they could be synthesized by $\mathrm{CO}_{2}$, it is favorable for the environment. However, the kinetic inertness of $\mathrm{CO}_{2}$ is a singular hurdle to employ it as a reagent. To complete this reaction smoothly, it is necessary to enhance the pressure and/or temperature, which is not safe. Therefore, various catalysts have been developed, including metal oxide [55], alkali metal salt [56], transition metal complexes [57], and functional organic polymers $[58,59]$. However, it is still a challenge to develop a single component catalyst that would activate the $\mathrm{CO}_{2}$ in a benign situation such as low pressure and temperature in the absence of a solvent and co-catalyst.

Photocatalytic carbon dioxide reduction is a clean, cost-effective, environmentally friendly, and promising strategy that transforms carbon dioxide into hydrocarbon fuel by solar energy $[60,61]$. The photocatalytic reduction of carbon dioxide based on semiconductors to chemical fuels has attracted great attention from Inoue et al. Generally, the whole photocatalytic carbon dioxide reduction reaction involves three main processes: (I) optical absorption of semiconductors to produce electron hole pairs, (II) the electron hole pair is separated and transferred to the surface of a semiconductor, (III) the surface reaction of $\mathrm{H}_{2} \mathrm{O}$ oxidation and $\mathrm{CO}_{2}$ reduction. The overall performance of photocatalytic $\mathrm{CO}_{2}$ abatement depends on the thermodynamic and kinetic balance of the above three processes. In the past few decades, great efforts have been made to explore a broader range of photocatalysts for the solar spectrum response (process (i)), and efficient separation and transport of electron-hole pairs (process (ii)). Therefore, many comments have been published to show the achievements and progress in improving the efficiency of the two processes prior to photocatalytic $\mathrm{CO}_{2}$ reduction.

The other method is to capture and store $\mathrm{CO}_{2}$. During the past decade, various materials and processes have been developed in industrial applications and laboratories for the separation of $\mathrm{CO}_{2}$ from other gases, including amines [62], ionic liquids [63], polymers, microporous metal-organic frameworks (MOFs) [64-67], covalent organic frameworks (COFs) [68], and amorphous porous materials [69]. In this work, we would like to introduce the process of absorbing carbon dioxide from the typical amine, functional ionic liquid, and metal organic framework.

Conventional technology for industrial capture of $\mathrm{CO}_{2}$ largely relies on employing an aqueous solution of amines. Despite the high absorption capacity, inherent drawbacks are also serious, such as solvent loss, corrosion, ethanol-amine degradation, and high-energy demands for absorbent regeneration that are inconsistent with sustainability principles. Therefore, the exploration of specific absorbents with a high absorption capacity and satisfactory stability is urgently needed and represents a hot area in recent years.

Inspired by the aqueous solution of amines, aminobased ionic liquids have been developed to capture $\mathrm{CO}_{2}$. In 2002, Davis et al. first utilized amino-based ionic liquids to capture $\mathrm{CO}_{2}$, which is totally different from the aqueous solution of amines [70]. Aminobased ionic liquids combine the advantages of amino and ionic liquids, which greatly improve stability and reduce the loss of solvent in the absorption-desorption process. After that, various amino-based task-specified functionalized ionic liquids have been developed [71, 72].

The aforementioned two methods are those of chemical absorption. The energy required to regenerate is very high. Metal organic framework material is emerging in recent years, which is a kind of porous crystalline material. It is widely used in various fields, such as adsorption and separation in gas [73], catalysis [74], magnetic fields [75], fluorescense [76] and water purification [77]. MOFs can be as superior candidate materials either in gas adsorption or in liquid phase adsorption. Compared to conventional adsorbents, MOFs have possessed several advantages such as rich topological structure, mild synthetic conditions, and avoidable post-synthetic calcinations steps. The adsorption on MOFs is a physical process, which has good selectivity, large adsorption capacity, excellent stability, easy regeneration, and other tremendous advantages as compared with traditional materials [78]. MOFs would be potential materials for $\mathrm{CO}_{2}$ capture and storage, which is favorable for controlling and reducing the greenhouse effect.

However, there are many areas to be improved for the preparation and structure of MOFs. With the increasing depletion of fossil fuels and serious of greenhouse effect, it is necessary to develop MOFs to be suitable for the capture of $\mathrm{CO}_{2}$ on a large scale.

\section{Conclusions}

Excessive carbon dioxide emissions have already led to a series of environmental problems, such as melting glaciers, rising sea levels, the loss of a large number of tropical rain forests and wetlands, drought and desertification, etc. Therefore, the problem of excessive carbon dioxide emissions cannot be ignored. It is of great importance to take action to deal with the greenhouse effect caused by carbon dioxide, which requires the joint efforts of all parts. The development and utilization of renewable energy is the most effective solution to deal with the increasingly severe energy and environmental 
problems. The development of renewable energy is an important direction of global energy development. Both developed and developing countries treat renewable energies, such as solar and wind energy, as an important means to meet the challenges of energy security and climate change. In addition, the sequestration and conversion of carbon dioxide is also an effective way to reduce the greenhouse effect.

\section{Acknowledgements}

We gratefully acknowledge funding support from the National Natural Science Foundation of China (NSFC) (project No. 21676071), Postgraduate Research \& Practice Innovation Program of Jiangsu Province (project No. KYCX18-0520), and Fundamental Research Funds for the Central Universities (project No. 2018B712X14).

\section{Conflict of Interest}

The authors declare no conflict of interest.

\section{References}

1. Energy Q. BP Statistical Review of World Energy June 2006. An annual report prepared by the British Petroleum oil company (www. bp. com) last accessed November, 2006.

2. U.S. Energy Information Administration. (2012). International energy statistics. Retrieved October 18, 2015, from http://www.eia. gov/cfapps/ipdbproject/IEDIndex3. cfm?tid=2\&pid=2\&aid $=2$.

3. MITCHELL J.F.B. The "greenhouse" effect and climate change. Reviews of Geophysics, 27 (1), 115, 1989.

4. SONIL N., SIVAMOHAN N.R., SUSHANTA K.M., JANUSZ A.K. The progressive routesfor carbon capture and sequestration. Energy Science \& Engineering, 4 (2), 99, 2016.

5. MCGREGOR H. Regional climate goes global. Nature Geoscience, 11 (1), 18, 2018.

6. China Meteorological Administration. Released July 12, 2017. http://www.cma.gov.cn/2011xwzx/2011xqxxw/2011x qxyw/201707/t20170712_435009.html.

7. FEDOROFF N.V., BATTISTI D.S., BEACHY R.N., COOPER P.J.M., FRISCHHOFF D. A., HODGES C.N., KNAUF V.C., LOBELL D., MAZUR B.J., MOLDEN D., REYNOLDS M.P., RONALD P.C., ROSEGRANT M.W., SANCHEZ P.A., VONSHAK A., ZHU J.K. Radically rethinking agriculture for the 21st century. Science, 327 (5967), 833, 2010.

8. CHANDRAMOWLI S.N., FELDER F.A. Impact of climate change on electricity systems and markets-A review of models and forecasts. Sustainable Energy Technologies and Assessments, 5, 62, 2014.

9. STEWART C., HESSAMI M.A. A study of methods of carbon dioxide capture and sequestration - the sustainability of a photosynthetic bioreactor approach. Energy Conversion and Management, 46 (3), 403, 2005.
10. World Energy Council. World Energy Resources: 2013 Survey. http://www.worldenergy.org/publications/2013/ world-energy-resources-2013-survey.

11. DOWELL N.M., FENNELL P.S., SHAH N., MAITLAND G.C. The role of $\mathrm{CO}_{2}$ capture and utilization in mitigating climate change. Nature Climate Change, 7 (4), 243, 2017.

12. IEA. World energy outlook 2015. 2015. http://cn.knoema. com/qydprmf/iea-world-energy-outlook-2015.

13. REN21. Renewables 2017 global status report. Tech. rep. REN21-Renewable energy policy network for the 21st century. Paris: REN21 Secretariat; 2017. http://www.ren21. net/gsr 2017 full report en.

14. National Development and Reform Commission (NDRC). China renewable energy development report, 165, 5, 2006.

15. Solar PV power statistics for various years from NEA's website http://www.nea.gov.cn.

16. GB2589-81. The General Calculating Rule for Comprehensive Energy Consumption of China.

17. International Renewable Energy Agency. http://www. irena.org/.

18. HERBERT G.M.J., INIYAN S., SREEVALSAN E., RAJAPANDIAN S. A review of wind energy technologies. Renewable and Sustainable Energy Reviews, 11 (6), 1117, 2007.

19. LI C.B., CHEN H.Y., ZHU J., ZUO J., ZILLANTE G., ZHAO Z.Y. Comprehensive assessment of flexibility of the wind power industry chain. Renewable Energy, 74, 18, 2015.

20. ACKERMANN T., SÖDER L. Wind energy technology and current status: a review. Renewable and Sustainable Energy Reviews, 4 (4), 315, 2000.

21. LEUNG D.Y.C., YANG Y. Wind energy development and its environmental impact: a review. Renewable and Sustainable Energy Reviews, 16 (1), 1031, 2011.

22. GWEC. Global wind 2008 report. Technical report, Global Wind Energy Council; 2009.http://gwec.net/publications/ global-wind-report-2/the-global-wind-2008-report.

23. GWEC. Global wind 2009 report. Technical report, Global Wind Energy Council; 2010. http://gwec.net/publications/ global-wind-report-2/global-wind-report-2009.

24. GWEC. The Wind Power Report: Seventh Edition, 2010 Wind Power Report, 2010.http://gwec.net/publications/ global-wind-report-2/global-wind-report-2011.

25. GWEC. Global Wind Report 2011-Annual market update. http:/gwec.net/publications/global-wind-report-2/globalwind-report-2010-2.

26. GWEC. Global Wind Report 2012-Annual market update. http://gwec.net/publications/global-wind-report-2/globalwind-report-2012.

27. GWEC. Global Wind Report 2013-Annual market update. http:/gwec.net/publications/global-wind-report-2/globalwind-report-2013.

28. ARÁNTEGUI R.L., GONZÁLES J.S. JRC wind status report: Technology, market and economic aspects of wind energy in Europe. 2015.

29. GWEC. Global Wind Report 2015-Annual market update. http://gwec.net/publications/global-wind-report-2/globalwind-report-2015-annual-market-update.

30. GWEC. Global Wind Report 2016-Annual market update. http:/gwec.net/publications/global-wind-report-2/globalwind-report-2016.

31. SUN Y., WU J., LI G.J. Influence research of wind power generation on power systems. Power System Technology, 31 (20), 55, 2007.

32. GLEICK P.H. Water and energy. Annual Review of Energy and the Environment, 19 (1), 267, 1994. 
33. AKPINAR A., KÖMÜRCÜ M.İ., KANKAL M. Development of hydropower energy in Turkey: the case of Coruh river basin. Renewable and Sustainable Energy Reviews, 15 (2), 1201, 2011.

34. PAN F., ZHAO L. AHP Comprehensive Evaluation on Sustainable Utilization of Water Resources in Hengshui City, China. Transactions of Tianjin University, 21 (2), 178, 2015.

35. CAI Q.Correctly disposing the relation of protection and development, reasonably developing the water power resources of the Nujiang river basin. Yangtze River, 36, 1, 2005.

36. ZHENG T., QIANG M., WANG J., ZHANG D.Evaluation of hydropower resource value of hydropower projects: Case study of Three Gorges Project. Journal of Hydroelectric Engineering, 35 (6), 39, 2016.

37. BARBIER E. Geothermal energy technology and current status: an overview. Renewable and Sustainable Energy Reviews, 6 (1), 3, 2002.

38. LUND J.W., BOYD T.L. Direct utilization of geothermal energy 2015 worldwide review. Geothermics, 60, 66, 2016.

39. HOU J.C., CAO M.C., LIU P.K. Development and utilization of geothermal energy in China: Current practices and future strategies. Renewable Energy, 125, 401, 2018.

40. ZHAO X., WAN G. Current situation and prospect of China's geothermal resources. Renewable Sustainable Energy Reviews, 32, 651, 2014.

41. ZHU J., HU K., LU X., HUANG X., LIU K., WU X. A review of geothermal energy resources, development, and applications in china: current status and prospects. Energy, 93, 466, 2015.

42. YUAN X.L., WANG X.J., ZUO J. Renewable energy in buildings in china - a review. Renewable and Sustainable Energy Reviews, 24 (10), 1, 2013.

43. LUND J.W., FREESTON D.H., BOYD T L. Direct utilization of geothermal energy 2010 worldwide review. Geothermics 40, 159, 2011.

44. ERIKSSON E., Thinning operations and their impact on biomass production in stands of Norway spruce and scots pine. Biomass \& Bioenergy, 30 (10), 848, 2006.

45. HECK V., GERTEN D., LUCHT W., POPP A.Biomassbased negative emissions difficult to reconcile with planetary boundaries.Nature Climate Change, 8, 151, 2018.

46. LISKA A.J., CASSMAN K.G. Towards standardization of life-cycle metrics for biofuels: greenhouse gas emissions mitigation and net energy yield. Journal of Biobased Materials and Bioenergy, 2 (3), 187, 2008.

47. ESCOBAR J.C., LORA E.S., VENTURINI O.J., YANEZ E.E., CASTILLO E.F., ALMAZAN O.Biofuels: environment, technology and food security. Renewable and Sustainable Energy Reviews, 13 (6), 1275, 2009.

48. THIN B.D., LIN C.Y., KUMAR G. Waste-to-wealth for valorization of food waste to hydrogen and methane towards creating a sustainable ideal source of bioenergy. Journal of Cleaner Production, 122, 29, 2016.

49. AJANOVIC A. Biofuels versus food production: Does biofuels production increase food prices? Energy, 36, 2070, 2011.

50. AYOUB M., ABDULlAH A.Z. Critical review on the current scenario and significance of crude glycerol resulting from biodiesel industry towards more sustainable renewable energy industry. Renewable and Sustainable Energy Reviews, 16 (5), 2671, 2012.
51. WELDEMICHAELY., ASSEFAG. Assessing the energy production and GHG (greenhouse gas) emissions mitigation potential of biomass resources for Alberta. Journal of Cleaner Production, 112, 4257, 2016.

52. CHEN A., CHEN C., XIU Y., LIU X., CHEN J., GUO L., ZHANG R., HOU Z. Niobate salts of organic base catalyzed chemical fixation of carbon dioxide with epoxides to form cyclic carbonates. Green Chemistry, 17(3), 1842, 2015.

53. ZHANG W., WANG Q., WU H., WU P., HE M. A highly ordered mesoporous polymer supported imidazoliumbased ionic liquid: an efficient catalyst for cycloaddition of $\mathrm{CO}_{2}$ with epoxides to produce cyclic carbonates. Green Chemistry, 16 (11), 4767, 2014.

54. ALVES M., GRIGNARD B., MEREAU R., JEROME C., TASSAING T., DETREMBLEUR C. Organocatalyzed coupling of carbon dioxide with epoxides for the synthesis of cyclic carbonates: catalyst design and mechanistic studies. Catalysis Science and Technology, 7 (13), 2651, 2017.

55. TIAN D., LIU B., GAN Q., LI H., DARENSBOURG D.J.Formation of cyclic carbonates from carbon dioxide and epoxides coupling reactions efficiently catalyzed by robust, recyclable one-component aluminum-salen complexes. ACS Catalysis, 2, 2029, 2012.

56. GUO L., WANG C., LUO X., CUI G., LI H. Probing catalytic activity of halide salts by electrical conductivity in the coupling reaction of $\mathrm{CO}_{2}$ and propylene oxide. Chemical Communications, 46 (32), 5960, 2010.

57. DECORTES A., HAAK R.M., MARTIN C., BELMONTE M.M., MARTIN E.,BENET-BUCHHOLZ J., KLEIJ A.W. Copolymerization of $\mathrm{CO}_{2}$ and cyclohexene oxide mediated by $\mathrm{Yb}$ (salen)-based complexes. Macromolecules, 48 (22), 8197, 2015.

58. XIONG Y., WANG H., WANG R., YAN Y.,ZHENG B., WANG Y. Cheminform abstract: a facile one-step synthesis of cross-linked polymeric nanoparticles as highly active and selective catalysts for cycloaddition of $\mathrm{CO}_{2}$ to epoxides. Chemical Communications, 46 (19), 3399, 2010.

59. ZHOU H., ZHANG W.Z., LIU C.H., QU J.P., LU X.B. $\mathrm{CO}_{2}$ adducts of N-heterocyclic carbenes: thermal stability and catalytic activity toward the coupling of $\mathrm{CO}_{2}$ with epoxides.Journal of Organic Chemistry,73 (20), 8039, 2008.

60. RAN J.R., JARONIEC M.,QIAO S.Z. Cocatalysts in semiconductor-based photocatalytic $\mathrm{CO}_{2}$ reduction: achievements, challenges, and opportunities. Advanced Materials, 30 (7), 1704649, 2018.

61. LOW J.X., QIU S.Q., XU D.F., JIANG C.J., CHENG B. Direct evidence and enhancement of surface plasmon resonance effect on $\mathrm{Ag}$-loaded $\mathrm{TiO}_{2}$ nanotube arrays for photocatalytic $\mathrm{CO}_{2}$ reduction. Applied Surface Science, 434, 423, 2018.

62. LIU A.H., MA R., SONG C., YANG Z.Z., YU A., CAI Y., HE L.N., ZHAO Y. N., YU B., SONG Q.W. Equimolar $\mathrm{CO}_{2}$ capture by $\mathrm{N}$-substituted amino acid salts and subsequent conversion.Angewandte Chemie International Edition, 51 (45), 11306, 2012.

63. GUI G., WANG J., ZHANG S. Active chemisorption sites in functionalized ionic liquids for carbon capture.Chemical Society Reviews, 45, 4307, 2016.

64. SUMIDA K., ROGOW D.L.,MASON J.A., MCDONALD T.M.,BLOCH E.D.,HERM Z.R.,BAE T.H., LONG J.R. Carbon dioxide capture in metal-organic frameworks. ChemicalReviews, 112 (2), 724, 2011. 
65. YU J.M., XIE L.H., LI J.R., MA Y.G., SEMINARIO J.M., BALBUENA P.B. $\mathrm{CO}_{2}$ capture and separations using mofs: computational and experimental studies. Chemical Reviews, 117 (14), 9674, 2017.

66. ÁLVAREZ J.R., MILEO P.G.M., SÁNCHEZ-GONZÁLEZ E., ZÁRATE J.A., RODRÍGUEZ-HERNÁNDEZ J., GONZÁLEZ-ZAMORA E., MAURIN G., IBARRA I.A. Adsorption of 1-propanol in the channel-like InOF1 metal-organic framework and its influence on the $\mathrm{CO}_{2}$ capture performances. Journal of Physical Chemistry C, 122, 5566, 2018.

67. JIN C., ZHANG S., ZHANG Z., CHEN Y. Mimic carbonic anhydrase using metal-organic frameworks for $\mathrm{CO}_{2}$ capture and conversion. Inorganic Chemistry. 57 (4), $2169,2018$.

68. FURUKAWA H., YAGHI O.M. Storage of hydrogen, methane, and carbon dioxide in highly porous covalent organic frameworks for clean energy applications. Journal of the American Chemical Society, 131 (25), 8875, 2009.

69. MAHURIN S.M., GORKA J., NELSON K.M., MAYES R.T., DAI S. Enhanced $\mathrm{CO}_{2} / \mathrm{N}_{2}$ selectivity in amidoximemodified porous carbon. Carbon, 67 (2), 457, 2014.

70. MATES E.D., MAYTON R.D., NTAI I., DAVIS J.H. $\mathrm{CO}_{2}$ capture by a task-specific ionic liquid. Journal of the American Chemical Society, 124 (6), 926, 2002.

71. JIANG Y.Y., WANG G.N., ZHOU Z., WU Y.T., GENG J., ZHANG Z.B. Tetraalkylammonium amino acids as functionalized ionic liquids of low viscosity. Chemical Communications, 8 (4), 505, 2008.

72. ZHANG Y., ZHANG S., LU X., ZHOU Q., FAN W., ZHANG $X$. Dual amino-functionalised phosphonium ionic liquids for $\mathrm{CO}_{2}$ capture. Chemistry-A European Journal, 15 (12), 3003, 2009.
73. KONG X., DENG H., YAN F., KIM J., SWISHER J.A., SMIT B.,YAGHI O.M., REIMER J.A. Mapping of functional groups in metal-organic frameworks. Science, 341 (6148), 882, 2013.

74. ZALOMAEVA O.V., CHIBIRYAEV A.M., KOVALENKO K.A., KHOLDEEVA O. A., BALZHINIMAEV B.S., FEDIN V.P. Cyclic carbonates synthesis from epoxides and $\mathrm{CO}_{2}$ over metal-organic framework Cr-MIL-101. Journal of Catalysis, 298 (298), 179, 2013.

75. MUNN A.S., CLARKSON G.J., MILLANGE F., DUMONT Y., WALTON R.I. M(II) (M = Mn, Co, Ni) variants of the MIL-53-type structure with pyridine-Noxide as a co-ligand. CrystEngComm, 15 (45), 9679, 2013.

76. KENT C.A., LIU D.M., ITO A., ZHANG T., BRENNAMAN M.K., MEYER T.J.,LIN W.B. Rapid energy transfer in non-porous metal-organic frameworks with caged $\mathrm{Ru}(\mathrm{bpy})_{3}{ }^{2+}$ chromophores: oxygen trapping and luminescence quenching. Journal of Materials Chemistry A, 1 (47), 14982, 2013.

77. FENG Y.F., JIANG H., LI S.N., WANG J., JING X.Y., WANG Y.R., CHEN M. Metal-organic frameworks HKUST-1 for liquid-phase adsorption of uranium. Colloids and Surfaces A Physicochemical and Engineering Aspects, 431 (2), 87, 2013.

78. FORGAN R.S., SMALDONE R.A., GASSENSMITH J.J., FURUKAWA H., CORDES D. B., LI Q.W., WILMER C.E., BOTROS Y.Y., SNURR R.Q., SLAWIN A.M.Z., STODDART J.F. Nanoporous carbohydrate metal-organic frameworks. Journal of the American Chemical Society, 134 (1), 406, 2012. 